\title{
Residual feed intake and relationships with performance of Nellore cattle selected for post weaning weight ${ }^{1}$
}

\author{
Tatiana Lucila Sobrinho², Renata Helena Branco ${ }^{3}$, Sarah Figueiredo Martins Bonilha ${ }^{3}$, André \\ Michel de Castilhos ${ }^{2}$, Leopoldo Andrade de Figueiredo ${ }^{3}$, Alexander George Razook ${ }^{3}$, \\ Maria Eugênia Zerlotti Mercadante ${ }^{3}$
}

1 Projeto financiado pela FAPESP.
2 Programa de Pós-graduação em Zootecnia, FMVZ/Unesp - Botucatu, SP.
${ }^{3}$ Centro APTA Bovinos de Corte, Instituto de Zootecnia - Sertãozinho, SP.

ABSTRACT - The objective of this work was to evaluate performance, efficiency parameters and phenotypic correlations among measurements of energy efficiency of Nellore cattle selected for post weaning weight and classified according to residual feed intake, calculated by the difference between observed and predicted intake, based on average metabolic body weight and average daily gain. Thus, animals were classified within three groups: high $(>$ mean +0.5 standard deviation, less efficient); medium $( \pm 0.5$ standard deviation of the mean); and low ( $<$ mean -0.5 standard deviation, more efficient) residual feed intake. No differences were observed at initial and final body weights, average daily gain and dry matter intake among groups. Animals with low residual feed intake also had greater feed efficiency, feed conversion and partial efficiency of growth and did not differ from the other animals regarding to relative growth rate and Kleiber ratio. Residual feed intake was significantly correlated to feed efficiency ( -0.25$)$, feed conversion (0.25), partial efficiency of growth $(-0.37)$ and dry matter intake $(0.16)$ but it did not present significant correlation with body weight (0.04), average daily gain (-0.02), relative growth rate $(-0.03)$ and Kleiber ratio (-0.05). Significant correlations were found between feed conversion and initial body weight (0.34) and average daily gain (-0.46). Partial efficiency of growth presented significant correlation with all other efficiency parameters analyzed. Residual feed intake has high potential in productive efficiency, when compared to the other energy efficiency measurements, being independent of growth and size of the animals.

Key Words: beef cattle, efficiency parameters, selection

\section{Consumo alimentar residual e relações com o desempenho de bovinos Nelore selecionados para peso pós-desmame}

\footnotetext{
RESUMO - Objetivou-se com este trabalho avaliar desempenho, parâmetros de eficiência e correlações fenotípicas entre medidas de eficiência energética de animais Nelore selecionados para peso pós-desmame e classificados quanto ao consumo alimentar residual, calculado pela diferença entre o consumo observado e o predito, com base no peso vivo médio metabólico e no ganho médio diário. Assim, os animais foram classificados em três grupos: alto ( $>$ média $+0,5$ desviopadrão; menos eficientes); médio ( \pm 0,5 desvio-padrão da média); e baixo (< média - 0,5 desvio padrão; mais eficientes) consumo alimentar residual. Não foram observadas diferenças nos pesos vivos inicial e final, no ganho médio diário e no consumo de matéria seca entre os grupos. Animais com baixo consumo alimentar residual mostraram-se também com melhor eficiência alimentar, conversão alimentar e eficiência parcial de crescimento e não apresentaram diferenças em relação aos outros grupos quanto à taxa de crescimento relativo e taxa Kleiber. O consumo alimentar residual apresentou correlação significativa com eficiência alimentar $(-0,25)$, conversão alimentar $(0,25)$, eficiência parcial de crescimento $(-0,37)$ e consumo de MS $(0,16)$ e não apresentou correlação significativa com peso vivo $(0,04)$, ganho médio diário $(-0,02)$, taxa de crescimento relativo $(-0,03)$ e taxa de Kleiber $(-0,05)$. Foram encontradas correlações significativas entre conversão alimentar e peso vivo inicial $(0,34)$ e ganho médio diário $(-0,46)$. Eficiência parcial de crescimento apresentou correlação significativa comtodos os outros parâmetros de eficiência analisados. O consumo alimentar residual, em comparação às demais medidas de eficiência energética, apresenta grande potencial na eficiência produtiva, sendo independente de crescimento e tamanho dos animais.
}

Palavras-chave: bovinos de corte, parâmetros de eficiência, seleção 


\section{Introduction}

Feed efficiency improvement is a major concern in animal production, therefore technological advances have been generated to quantify feed intake by an easy and low cost manner (Basarab et al., 2003). Residual feed intake is the difference between the expected intake of the animal and what it actually consumes, based on its metabolic weight and average daily gain. Another definition is the selection toll not dependent on growth traits as conversion or feed efficiency (Koch et al., 1963). This fact has been demonstrated in studies performed with feedlot animals (Arthur et al., 2001), proving that there are no genetic correlations between residual feed intake and metabolic body weight and average daily gain (-0.06 and -0.04 , respectively). Therefore, no alterations are observed upon the adult size or growth of animals selected for residual feed intake.

After five years of diverging selection, Australian scientists confirmed that the selection of animals for efficiency (low residual feed intake) resulted in a progeny of lower intake and slightly thinner, but the performance was similar to the animals selected for high residual feed intake (Arthur et al., 2008). However, those results of residual feed intake diverge on age and production system. Herd et al. (2004) observed that initial and final body weight of heifers grazing pasture of medium quality was not associated to intake or residual feed intake. Also, average daily gain tended for a negative association with residual feed intake.

Reports in literature on values of standard deviation for residual feed intake of animals from different breeds or crossbreds (0.74 kg/day - Arthur et al., 2001; 0.82 kg/day Carstens, et al., 2002; 0.66 kg/day - Basarab et al., 2003; $1.05 \mathrm{~kg}$ /day - Almeida et al., 2004; $0.287 \mathrm{~kg} /$ day -Castilhos et al., 2010) confirm that intake varies widely among individuals. This variation can be explored by selecting animals that consume less, without altering performance traits. Still, residual feed intake heritability of taurine cattle was classified within low to moderate levels (0.24-Nkrumah et al., 2007; and 0.21 - Arthur et al., 2001), then, approximately $33 \%$ of the observed variations are mainly due to additive genes and, therefore, can be genetic manipulated. That trait has not been calculated for zebu cattle, yet.

There are not many studies on performance traits and residual feed intake in literature,thus the objective of this work was to report efficiency parameters evaluations and phenotypic correlations among different measurements of energy efficiency of animals selected for post weaning weight and classified according to residual feed intake.

\section{Material and Methods}

The experiment was conducted at Centro APTA Bovinos de Corte, Instituto de Zootecnia, Sertãozinho, São Paulo state, Brazil. This region is characterized by a tropical humid climate $\left(21^{\circ} 10^{\prime}, 48^{\circ} 05^{\prime}\right)$, with annual average temperature of $24^{\circ} \mathrm{C}$ and average annual precipitation of $1,888 \mathrm{~mm}$.

The breeding program of the Instituto de Zootecnia began in 1976 to enhance post weaning weight, manipulating, within biological boundaries, the equation of the genetic gain with selection based on individual performance (Razook et al., 1997). Genetic change at post weaning weight is evaluated based on Control Nellore herd (NeC), which was selected to null selection differential whereas Selection Nellore herd (NeS) was selected for higher selection differentials for standardized weight at 378 days of age.

Two experiments were performed in the years 2007 and 2008 , respectively, with $26^{\text {th }}$ and $27^{\text {th }}$ calf crops of the breeding program. The Feeding Performance Tests of this years were performed with 121 Nellore bulls from the two herds. In the experiment 1 (2007), 60 animals were used (41 from $\mathrm{NeS}$ and 19 from $\mathrm{NeC}$ herds), and in the experiment 2 (2008), 34 bulls from NeS herd and 27 from $\mathrm{NeC}$, totaling 61 animals.

After weaning, animals were allocated in individual pens for 168 days, being the first 56 days for adaptation to facilities and diet and 112 days for data collection. This period was longer than the ones found in literature for residual feed intake analysis (70 days - Archer et al., 1997), but when animals from experiment were submitted to the feeding performance test, they received the same treatment of the others.

Diet was composed of brachiaria hay, ground corn, cottonseed meal and mineral salt and were provided twice a day (8:00 a.m. and 3:00 p.m.), ad libitum (Table 1). Chemical analysis of feed and leftovers were performed in the Laboratório de Bromatologia of Departamento de Melhoramento e Nutrição Animal at Faculdade de Medicina Veterinária e Zootecnia of UNESP, Botucatu Campus.

Weight measurements of all animals were taken every 28 days, after fasting of solid feed (16 hours): the first measure, after acclimation to individual feedlot, represented the initial body weight and the last, at 168 days of experiment, represented the final body weight. Average daily gain was calculated from measurements of weight and number of experimental days.

Voluntary intake of each animal was calculated by the difference between offered feed and leftovers. The leftovers 
were weighed daily and sampled weekly at $10 \%$ of its weight adjusted to keep 5 and $10 \%$ of the total feed offered. Four samples composed by leftovers were collected from each animal, according to 28-d interval between weightings and frozen.

Samples of feed and leftovers were previously ovendried $\left(55^{\circ} \mathrm{C}\right)$ during 72 hours and grounded using a Wiley mill with a $2 \mathrm{~mm}$ screen. Samples of definitive dry matter (DM) were oven-dried at $105^{\circ} \mathrm{C}$ for 8 hours. Feed samples were analyzed for neutral detergent fiber (Van Soest et al., 1991) and crude protein (Silva \& Queiroz, 2002).

Energy level of feed was calculated as TDN $=0.98 \times$ $\left(100-\mathrm{NDF}_{\mathrm{cp}}-\mathrm{CP}-\mathrm{ash}-\mathrm{EE}-1\right)+0.93 \times \mathrm{CP}+2.25 \times \mathrm{EE}$ $+0.75 \times\left(\mathrm{NDF}_{\mathrm{cp}}-\right.$ lignin $) \times\left[1-\left(\right.\right.$ lignin $\left.\left./ \mathrm{NDF}_{\mathrm{cp}}\right) \times 0.667\right]$ -7 (Weiss, 1992).

Residual feed intake was calculated as the difference between the observed and expected dry matter intake of the animal, predicted by regression equation as a function

Table 1 - Percentage and chemical composition of the diet

\begin{tabular}{lcc}
\hline Item & Experiment & Experiment 2 \\
\hline Composition of diet (\% DM) & & \\
Brachiaria brizantha hay & 44.9 & 44.5 \\
Ground corn & 31.9 & 32.2 \\
Cottonseed meal & 21.5 & 21.4 \\
Urea & - & 0.48 \\
Ammonium sulfate & - & 0.05 \\
Mineral salt & 1.70 & 1.40 \\
Chemical composition & & \\
Dry matter (\%) & 90.3 & 88.8 \\
Crude protein (\% DM) & 11.2 & 13.1 \\
Neutral detergent fiber (\% DM) & 51.6 & 52.7 \\
Total carbohydrates ${ }^{1}$ (\% DM) & 80.4 & 79.5 \\
Total digestible nutrients (\% DM) & 59.8 & 59.1 \\
Metabolizable energy (Mcal/kg DM) & 2.25 & 2.23 \\
Neutral detergent fiber of roughage & 35.4 & 34.7 \\
origin (\% DM) & & \\
Roughage:concentrate ratio & $45: 55$ & $45: 55$ \\
\hline 1 & &
\end{tabular}

${ }^{1}$ Calculated according to NRC (1996). of average metabolic weight and average daily gain (Koch et al., 1963). According to residual feed intake, cattle was classified as high (> mean +0.5 standard deviation less efficient), medium ( \pm 0.5 standard deviation from mean) and low ( $<$ mean - 0.5 standard deviation - most efficient).

Feed conversion was calculated as the ratio between dry matter intake and average daily gain and feed efficiency was calculated as the ratio between average daily gain and dry matter intake. Partial efficiency of growth was calculated as the ratio between average daily gain and the difference between average daily dry matter intake and the estimated for maintenance (Arthur et al., 2001), and dry matter intake for maintenance was obtained from NRC (1996).

Relative growth rate (RGR) was calculated by the following equation: RGR $=100 \times(\log \mathrm{FBW}-\log \mathrm{IBW}) /$ days of experiment, in which FBW = final body weight and IBW initial body weight (Fitzhugh \& Tailor, 1971). Kleiber ratio was calculated as the ratio between average daily gain and average metabolic body weight (Bergh et al., 1992; Arthur et al., 2001).

The experimental design used was a completely randomized. The variables year (experiments 1 and 2) and herd (control and selection) were analyzed by using GLM procedure from SAS (SAS, 1999), being not significant $(\mathrm{P}>0.05)$ and removed from statistical. Means were compared by the Tukey test at $5 \%$ of probability level. Pearson correlations among tested traits were calculated by CORR procedure from SAS (SAS, 1999).

\section{Results and Discussion}

In experiments 1 and 2, respectively, no significant differences were detected for final body weight (298 and $286 \mathrm{~kg})$ and average daily gain $(0.830$ and $0.820 \mathrm{~kg})$ (Table 2). Initial body weight of the animals from experiment $1(205 \mathrm{~kg})$ tended to be higher $(\mathrm{P}=0.070)$ than

Table 2 - Means of performance and feed efficiency traits in the years of experiment

\begin{tabular}{|c|c|c|c|}
\hline Trait & Experiment 1 & Experiment 2 & $\mathrm{P}$ \\
\hline Number of animals & 60 & 61 & - \\
\hline Initial body weight (kg) & $205 a \pm 31$ & $194 a \pm 36$ & 0.070 \\
\hline Final body weight $(\mathrm{kg})$ & $298 a \pm 39$ & $286 a \pm 48$ & 0.135 \\
\hline Dry matter intake (kg/day) & $6.37 \mathrm{a} \pm 0.86$ & $6.07 \mathrm{a} \pm 1.00$ & 0.082 \\
\hline Dry matter intake (\%BW) & $2.55 a \pm 0.16$ & $2.54 \mathrm{a} \pm 0.18$ & 0.846 \\
\hline Dry matter intake $\left(\% \mathrm{BW}^{0.75}\right)$ & $101 \mathrm{a} \pm 6.6$ & $100 \mathrm{a} \pm 7.3$ & 0.249 \\
\hline Feed efficiency (g gain/kg DM) & $130 \mathrm{~b} \pm 14$ & $135 \mathrm{a} \pm 14$ & 0.033 \\
\hline Partial efficiency of growth ( $\mathrm{kg}$ gain $/ \mathrm{kg} \mathrm{DM}$ ) & $0.32 b \pm 0.04$ & $0.34 \mathrm{a} \pm 0.05$ & 0.017 \\
\hline Relative growth rate (kg BW/day) & $0.14 \mathrm{a} \pm 0.02$ & $0.15 a \pm 0.02$ & 0.101 \\
\hline Kleiber ratio (kg gain $/ \mathrm{kg} \mathrm{BW}^{0.75}$ ) & $0.01 \mathrm{a} \pm 0.001$ & $0.01 \mathrm{a} \pm 0.001$ & 0.250 \\
\hline
\end{tabular}

Means followed by the same letter, in lines, do not differ significantly by Tukey test at $5 \%$ of probability. 
those of experiment $2(194 \mathrm{~kg})$. When experimental herds were closed, animals were very homogeneous in body size and weight gain, parameters relatively constant within the analyzed years. The few differences observed may be explained by the variation of the quality of the roughage in diet.

Dry matter intake expressed as kg/day of experiment 1 tended to be higher $(P=0.082)$ and this can be explained by the different weights of the animals at the beginning of the experiments. When dry matter intake was corrected by body weight and metabolic body weight, no significant differences were observed. Regression equations for dry matter intake prediction obtained from 2007 and 2008 experimental data were: experiment 1 : DMI estimated $=$ $-1.301+2.301 \times$ ADG $+0.092 \times \mathrm{BW}^{0.75}\left(\mathrm{r}^{2}=0.89\right)$; experiment 2 : DMI estimated $=-0.952+2.558 \times \mathrm{ADG}+0.081$ $\times \mathrm{BW}^{0.75}\left(\mathrm{r}^{2}=0.89\right)$, in which: $\mathrm{BW}^{0.75}=$ average metabolic body weight (kg) and ADG = average daily gain (kg/day). Average dry matter intake of the experiments was $6.21 \mathrm{~kg} /$ day, representing $2.54 \%$ of the body weight (Table 3 ).

Residual feed intake did not differ between experiments $(\mathrm{P}>0.05)$. However, as the animals presented similar weight gains and different dry matter intakes, there were differences in feed conversion and feed efficiency among the years of experiment. In experiment 2 , the animals presented greater feed efficiency, partial efficiency of growth and feed conversion (130 vs. 135 ; 0.32 vs. 0.34 ; and 7.77 vs. 7.47, respectively). Mean obtained for residual feed intake was $-0.001 \pm 0.313 \mathrm{~kg} /$ day, with minimum and maximum values of -0.670 and $+0.950 \mathrm{~kg} / \mathrm{day}$, respectively, confirming the phenotypic variance for this trait in Nellore animals, being the difference of intake between less and more efficient animals $1.620 \mathrm{~kg}$ of DM/day.

Relative growth rate and Kleiber ratio did not differ significantly among years of experiment and this indicates that the animals maintained the average weight and weight gain during those years because when these ratios were calculated, these traits were considered.

Lanna \& Almeida (2004), working with zebu cattle from different origins and compensatory gains, found higher standard deviation for residual feed intake ( $1.05 \mathrm{~kg} / \mathrm{day})$. In this work, the value found for residual feed intake standard deviation was lower $(0.313 \mathrm{~kg} /$ day $)$, due to homogeneity and the same origin of the animals.

Lancaster et al. (2009) observed minimum and maximum values for residual feed intake of $-2.46 \mathrm{~kg} /$ day and $+2.58 \mathrm{~kg} /$ day for growing Angus, a much larger amplitude than the one observed in this study. That research was performed with four different experiments, at different times in the year (Summer and Winter of 2004 and 2005), therefore data tended to a higher dispersion, which may explain that amplitude. Also, the high energy density of the diet (2.59 to $2.88 \mathrm{Mcal}$ of ME/kg) would bring higher digestibility, with higher intake and, therefore, higher variation between the less and more efficient animals.

Animals from Selection Nellore herd (NeS), at a same age, presented higher $(\mathrm{P}<0.001)$ initial body weight $(212 \mathrm{vs}$. $178 \mathrm{~kg}$ ), final body weight (313 vs. $256 \mathrm{~kg}$ ) and average daily gain (0.898 vs. $0.701 \mathrm{~kg} /$ day) than Control Nellore herd (NeC) (Table 4).

Selection for weight performed in the animals from Selection Nellore herd provided a difference of approximately $60 \mathrm{~kg}$ of body weight at the end of feeding performance test when compared to Control Nellore herd (Mercadante et al., 2004).

Dry matter intake expressed as kg/day and g/kg BW ${ }^{0.75}$ were significantly different $(\mathrm{P}<0.001)$ among herds and were higher for Selection Nellore. When expressed in percentage of body weight, no significant differences were detected among herds $(\mathrm{P}=0.502)$. Selection Nellore herd presented better feed conversion $(\mathrm{P}=0.011)$, feed efficiency $(\mathrm{P}=0.011)$, relative growth rate $(\mathrm{P}=0.017)$ and Kleiber ratio

Table 3 - Means, standard deviations, minimum and maximum values of performance traits of Nellore cattle

\begin{tabular}{|c|c|c|c|c|}
\hline Trait & Mean & Standard deviation & Minimum & Maximum \\
\hline Initial body weight (kg) & 199 & 34.0 & 128 & 301 \\
\hline Final body weight (kg) & 292 & 44.0 & 194 & 394 \\
\hline Body weight $0.75(\mathrm{~kg})$ & 61.9 & 7.31 & 45.3 & 80.5 \\
\hline Average daily gain (kg/day) & 0.82 & 0.14 & 0.43 & 1.18 \\
\hline Dry matter intake (kg/day) & 6.21 & 0.94 & 3.99 & 8.24 \\
\hline Dry matter intake (\%BW) & 2.54 & 0.17 & 2.13 & 3.00 \\
\hline Dry matter intake $\left(\% \mathrm{BW}^{0.75}\right)$ & 100 & 6.93 & 82.4 & 118 \\
\hline Residual feed intake (kg DM/day) & -0.001 & 0.313 & -0.670 & 0.950 \\
\hline Feed conversion (kg DM/g gain) & 7.62 & 0.87 & 5.99 & 11.6 \\
\hline Feed efficiency (g gain $/ \mathrm{kg}$ ) & 133 & 14.1 & 86.5 & 167 \\
\hline Partial efficiency of growth (kg gain $/ \mathrm{kg}$ DM) & 0.33 & 0.05 & 0.20 & 0.51 \\
\hline Relative growth rate (kg BW/day) & 0.14 & 0.02 & 0.10 & 0.19 \\
\hline Kleiber ratio $\left(\mathrm{kg}\right.$ gain $\left./ \mathrm{kg} \mathrm{BW}^{0.75}\right)$ & 0.010 & 0.001 & 0.009 & 0.017 \\
\hline
\end{tabular}


Table 4 - Performance traits of Nellore cattle selected for post weaning weight

\begin{tabular}{|c|c|c|c|}
\hline \multirow[b]{2}{*}{ Trait } & \multicolumn{2}{|c|}{ Herd } & \multirow[b]{2}{*}{$\mathrm{P}$} \\
\hline & Control Nellore & Selection Nellore & \\
\hline Number of animals & 46 & 75 & -- \\
\hline Final body weight $(\mathrm{kg})$ & $257 b \pm 30$ & $313 a \pm 37$ & $<0.001$ \\
\hline Average daily gain $(\mathrm{kg} /$ day $)$ & $0.701 \mathrm{~b} \pm 0.092$ & $0.898 \mathrm{a} \pm 0.104$ & $<0.001$ \\
\hline Dry matter intake (kg/day) & $5.47 \mathrm{~b} \pm 0.656$ & $6.67 \mathrm{a} \pm 0.796$ & $<0.001$ \\
\hline Residual feed intake (kg DM/day) & $0.028 \mathrm{a} \pm 0.325$ & $-0.018 \mathrm{a} \pm 0.307$ & 0.424 \\
\hline Feed conversion (kg DM/g gain) & $7.87 \mathrm{a} \pm 0.96$ & $7.46 b \pm 0.77$ & 0.011 \\
\hline Feed efficiency (g gain $/ \mathrm{kg}$ ) & $129 b \pm 14$ & $135 a \pm 13$ & 0.011 \\
\hline Partial efficiency of growth ( $\mathrm{kg}$ gain $/ \mathrm{kg} \mathrm{DM})$ & $0.34 \mathrm{a} \pm 0.06$ & $0.32 \mathrm{a} \pm 0.04$ & 0.133 \\
\hline Relative growth rate (kg BW/day) & $0.14 \mathrm{~b} \pm 0.02$ & $0.15 \mathrm{a} \pm 0.02$ & 0.017 \\
\hline Kleiber ratio, kg gain/kg (BW $\left.{ }^{0.75}\right)$ & $0.012 b \pm 0.001$ & $0.014 \mathrm{a} \pm 0.001$ & $<0.001$ \\
\hline
\end{tabular}

Means followed by same letter, in lines, do not differ significantly by the Tukey test at $5 \%$ of probability.

$(\mathrm{P}<0.001)$ when compared to Control Nellore. Feed conversion seems to be highly influenced by differences at growth and at maturity patterns of different animals while residual feed intake is not (Archer et al., 1999).

Hypothetically, by considering an animal from Selection Nellore herd that presented final body weight of $313 \mathrm{~kg}$ and dry matter intake of approximately $748 \mathrm{~kg}$ during the period, selected according to daily dry matter intake and feed efficiency, an animal from Control Nellore herd would need an average dry matter intake of $5.47 \mathrm{~kg} /$ day or $1054 \mathrm{~kg}$ of dry matter intake during the experimental period and also more 81 days in feedlot to achieve that same body weight. This difference represents an intake $30 \%$ higher for the non-selected animal showing the higher efficiency of the selected ones.

This result differ from the one presented by Almeida (2005), in a study with the $12^{\text {th }}, 13^{\text {th }}$ and $14^{\text {th }}$ calf crops from the same herds, born in the years of 1992, 1993 and 1994, respectively. In that study, selected animals presented higher initial and final body weight at the feeding performance test, and also higher average daily gain and dry matter intake, while Control Nellore cattle presented higher feed efficiency and lower residual feed intake. Those results show that Control Nellore was more efficient than Selection Nellore herd. That study was not designed to estimate differences on residual feed intake between selected cattle for post weaning weight, therefore the animals were disposed in couples in pens, and observed intake was estimated for each animal. This procedure may have influenced the results.

Among the animals classified as more efficient, with low residual feed intake (Figure 1), the observed intake was lower than the predicted for the same performance. Above the line, there are the animals of high residual feed intake (less efficient), with observed intake higher than the predicted. Because no differences were observed among animals from Control Nellore and Selection Nellore herds $(\mathrm{P}=0.424)$, a balance was observed in the data dispersion around the line.

Also, no differences were observed in partial efficiency of growth ( $\mathrm{P}=0.133$ ) among herds. According to Dittmar III (2007), residual feed intake and partial efficiency of growth include energy requirements for maintenance and production and they are more sensible to variations in the individual energy efficiency of animals. Thus, selection for post weaning weight resulted in larger animals, with higher gain rates, higher dry matter intake and with the same energy efficiency. This indicated that selection applied to the animals in the last 30 years did not alter their energy efficiency which would be expected when considering the growth rates of the herds.

According to Brown (2005), the requirements for basal metabolism may be influenced by factors such as energy balance, protein level, kind and amount of fiber in diet,

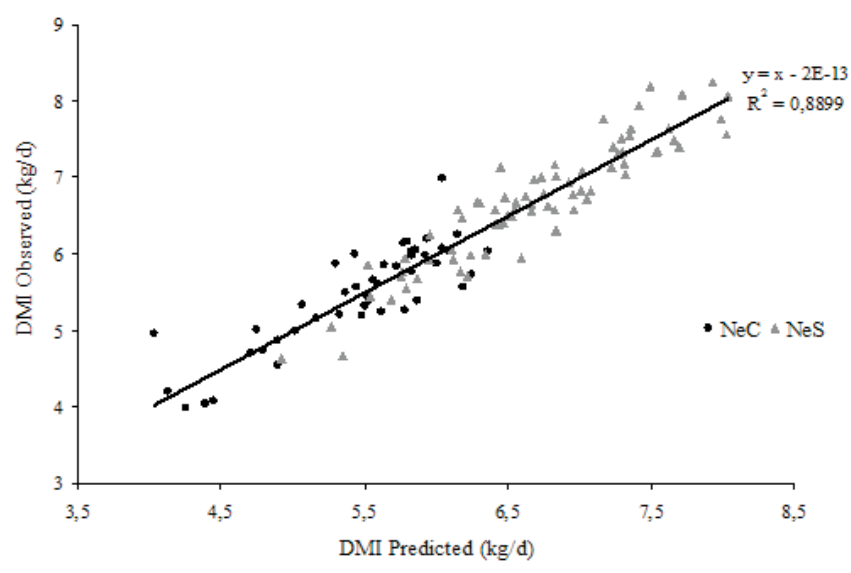

Figure 1 - Observed and predicted dry matter intake of animals selected for post weaning weight. 
activities and fecal excretion of energy. Because animals were fed the same diet, same energy and protein levels and same source of fibers, any increase or decrease of required energy for maintenance would be similar for everyone. Animals were kept in individual pens, under the same conditions of activity, which consisted basically in feeding and resting, therefore no disputes for feed or any other kind of interaction happened, which would result in energy losses. Variations in the feeding patterns could cause differences in energy wastes, just as the fecal excretion, but this data was not analyzed in this study.

Animals of high, medium, and low residual feed intake presented similar initial $(\mathrm{P}=0.766)$ and final $(\mathrm{P}=0.769)$ body weight and average daily gain $(\mathrm{P}=0.696)$. The use of linear regression for calculation adjusted residual feed intake for weight and gain, resulting in phenotypic independence of these traits (Table 5).

Dry matter intakes, as percentage of body weight and $\mathrm{g} / \mathrm{kg}$ of metabolic body weight, were higher for animals of high and medium intake when compared to those of low residual feed intake (2.60 and 2.57 vs. 2.46; 103 and 101 vs. 97.3, respectively), with no differences in dry matter intake (kg/day) for residual feed intake categories.

Cattle of low residual feed intake (more efficient) consumed less than $0.335 \mathrm{~kg} /$ day in DM than medium residual intake animals, and when compared to the animals of high residual intake it was $0.705 \mathrm{~kg} /$ day in DM. When a feedlot situation is considered and around $80 \%$ of costs are destined for feeding (Basarab et al., 2003), the identification of the animals which consume less with no impairment to production would bring large reductions of costs to the system. However, no significant differences were observed in DM intake ( $\mathrm{kg} /$ day) of the animals from both herds (Control Nellore and Selection Nellore) which had different feeding patterns.
Almeida et al. (2004), working with Nellore heifers, but older (26 months of age), noticed that animals of high residual feed intake consumed $26 \%$ more than the most efficient cattle, but the average daily gain was the same (1.3 kg/day). Carstens et al. (2002) and Basarab et al. (2003) found differences in dry matter intake between animals of low (21\%) and high (12\%) residual feed intake. Also, Richardson et al. (2004) verified that the difference of the intake between two groups of animals (less and more efficient) was lower in magnitude (6\%).

Genetic variation of feed intake seems to be predominantly, if not totally, explained by differences in energy costs related to maintenance by unit of metabolic size, when differences on rate and composition of weight gain are discounted (Nielsen, 2004). This has been one of the arguments around residual feed intake. Some authors have suggested that, beyond dry matter intake itself, some intake patterns vary between less and more efficient animals. Golden \& Kerley (2004) verified that more efficient animals consumed less feed and spent less time consuming diet (lower mouthful rate a day) than the less efficient animals. Herd et al. (2004), revising literature on physiological mechanisms related to residual feed intake, concluded that animals of high residual feed intake remained $13 \%$ more time in the feeding stalls than those of low residual feed intake. Due to this higher time, higher energy wastes may be added related to apprehension, chewing, rumination of diet, which according to Herd et al. (2004), represents $5 \%$ of the exceeding energy consumed by the less efficient animals compared to those more efficient. Beyond this association among longer time spent with activities related to intake and rumination of animals of high residual feed intake, another important aspect that may be influenced by this behavioral matter is the feed passage rate that may have effect upon diet digestibility.

Table 5 - Performance traits of Nellore cattle of high, medium and low residual feed intake

\begin{tabular}{|c|c|c|c|c|}
\hline \multirow[b]{2}{*}{ Trait } & \multicolumn{3}{|c|}{ Residual feed intake } & \multirow[b]{2}{*}{$\mathrm{P}$} \\
\hline & High & Medium & Low & \\
\hline Number of animals & 36 & 45 & 40 & - \\
\hline Final body weight $(\mathrm{kg})$ & $290 \mathrm{a} \pm 43$ & $289 a \pm 41$ & $296 a \pm 49$ & 0.769 \\
\hline Average daily gain (kg/day) & $0.81 \mathrm{a} \pm 0.12$ & $0.82 \mathrm{a} \pm 0.14$ & $0.83 a \pm 0.1$ & 0.696 \\
\hline Dry matter intake (kg/day) & $6.3 a \pm 1.0$ & $6.2 \mathrm{a} \pm 0.81$ & $6.1 \mathrm{a} \pm 1.04$ & 0.499 \\
\hline Residual feed intake (kg DM/day) & $0.370 \mathrm{a} \pm 0.2$ & $0.000 \mathrm{~b} \pm 0.07$ & $-0.335 c \pm 0.13$ & $<0.001$ \\
\hline Feed conversion (kg DM/kg gain) & $7.9 b \pm 0.9$ & $7.66 \mathrm{ab} \pm 0.9$ & $7.32 \mathrm{a} \pm 0.6$ & 0.014 \\
\hline Feed efficiency (g gain/kg DMI) & $128 b \pm 15$ & $132 \mathrm{ab} \pm 14$ & $138 \mathrm{a} \pm 12$ & 0.013 \\
\hline Partial efficiency of growth ( $\mathrm{kg}$ gain $/ \mathrm{kg} \mathrm{DM})$ & $0.30 \mathrm{~b} \pm 0.05$ & $0.32 b \pm 0.03$ & $0.35 a \pm 0.05$ & $<0.001$ \\
\hline Relative growth rate (kg BW/day) & $0.14 \mathrm{a} \pm 0.02$ & $0.14 \mathrm{a} \pm 0.02$ & $0.14 \mathrm{a} \pm 0.01$ & 0.861 \\
\hline Kleiber ratio (kg gain $/ \mathrm{kg} \mathrm{BW}^{0.75}$ ) & $0.01 \mathrm{a} \pm 0.001$ & $0.01 \mathrm{a} \pm 0.001$ & $0.01 \mathrm{a} \pm 0.001$ & 0.828 \\
\hline
\end{tabular}

Means followed by same letter, in lines, do not differ significantly by Tukey test at $5 \%$ of probability. 
In this study, animals of low residual feed intake were more feed efficient $(P=0.013)$ than the high ones. This difference of 7\% in efficiency is found near the ones observed by Basarab et al. (2003) and Baker et al. (2006), who found values of 9.4 and 13\% respectively, for heifers under diverging selection for residual feed intake.

Performance traits, residual growth rate and Kleiber ratio did not differ among residual feed intake levels. This happened because these rates take into consideration weight, gain and days of experiment, which were similar between less and more efficient animals. Nkrumah et al. (2004), evaluating efficiency traits, observed that residual growth rate and Kleiber ratio may not identify obvious differences of energy efficiency among animals.

Highly significant correlations (Table 6) were detected between dry matter intake and average daily gain (0.79), initial body weight (0.84) and final body weight (0.93), in accordance to the results found for growing cattle (Carstens et al., 2002; Nkrumah et al., 2007; Lancaster et al., 2009) and bulls (Arthur et al., 2001).

High and negative correlation was found between dry matter intake and partial efficiency of growth (-0.62), proving that animals which consume more for the same gain are not efficient. This happens because the partial efficiency of growth considers the difference between observed and estimated intake for maintenance, according to NRC (1996).

Residual feed intake presented low correlation with dry matter intake (0.16) but it was not correlated with body weight (0.04) and average daily gain (-0.02). Lancaster et al. (2009) observed that there is high correlation among residual feed intake and dry matter intake and that residual feed intake is independent of body weight and average daily gain, because the most efficient animals consume $16 \%$ less feed than the less efficient ones for the same performance. It has been demonstrated in many studies that residual feed intake is genetically independent of growth and size of growing cattle (Arthur et al., 2001) and heifers (Nkrumah et al., 2004), or presents low genetic correlation to body weight (Herd \& Bishop, 2000).

In this study, correlation between residual feed intake and feed conversion was moderate and positive $(0.25)$ whereas with feed efficiency $(-0.25)$ and partial efficiency of growth $(-0.37)$ it was negative, and no correlation with residual growth rate $(-0.03)$ and Kleiber ratio $(-0.05)$ was found. Partial efficiency of growth was $14 \%$ higher for the most efficient animals. Phenotypic correlations between residual feed intake and partial efficiency of growth for growing animals reported by Arthur et al., (2001), Nkrumah et al.(2004)

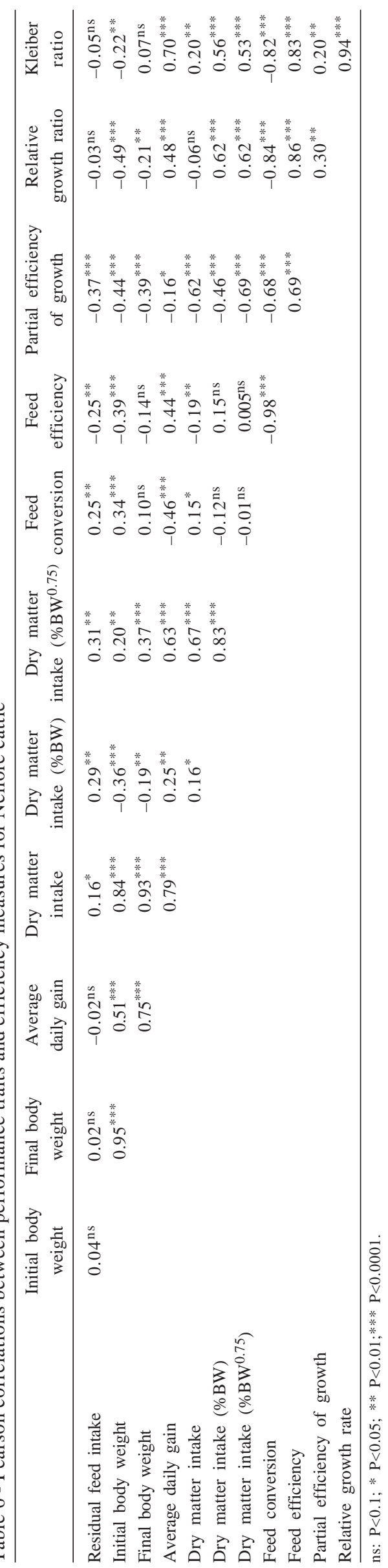

R. Bras. Zootec., v.40, n.4, p.929-937, 2011 
and Lancaster et al. (2009) were -0.65, 0.89 and -0.84, respectively. These results were expected because residual feed intake and partial efficiency of growth lead to the partition of intake requirements for maintenance and production.

The high correlations detected between partial efficiency of growth and feed conversion $(-0.68)$, dry matter intake (0.62) and residual feed intake $(-0.37)$ indicated that animals of low conversion, dry matter intake or residual feed intake may present significant reductions of the energy requirements for maintenance by increasing efficiency of growth upon maintenance. These results corroborate with those reported by Hoque et al. (2009), who found phenotypic correlation values among partial efficiency of growth and feed conversion, dry matter intake and residual feed intake of $0.32 ;-0.46$ and -0.76 , respectively.

However, partial efficiency of growth was highly correlated to initial $(-0.44)$ and final $(-0.39)$ body weight. Therefore, the responses to the selection for partial efficiency of growth may not be so independent from growth and size of the animals such as the ones found in selection for residual feed intake.

Average daily gain was correlated to feed efficiency $(0.44)$, feed conversion $(-0.46)$, relative growth rate $(0.48)$ and Kleiber ratio (0.70), and the best efficiency indices belong to the animals of higher weight gains. The selection based in these indices may result in increasing increases in maintenance requirements of the animals, which will consume more feed, especially when adult size is achieved (Archer et al., 1999).

\section{Conclusions}

Residual feed intake can be used as a tool to identify the most efficient animals. Among the efficiency traits analyzed, the residual feed intake present high potential to enhance productive efficiency without altering animal performance.

\section{References}

ALMEIDA, R. Consumo e eficiência alimentar de bovinos em crescimento. 2005. 181f. Tese (Doutorado em Agronomia) - Escola Superior de Agricultura “Luiz de Queiroz”/Universidade de São Paulo, Piracicaba.

ALMEIDA, R.; LANNA, D.P.D.; LEME, P.R. Consumo alimentar residual: um novo parâmetro para avaliar a eficiência alimentar de bovinos de corte. In: REUNIÃO ANUAL DA SOCIEDADE BRASILEIRA DE ZOOTECNIA, 41., 2004, Campo Grande. Anais... Campo Grande: Sociedade Brasileira de Zootecnia, 2004.

ARTHUR, P.F.; RENAND, G.; KRAUSS, D. Genetic and phenotypic relationships among different measures of growth and feed efficiency in young Charolais bulls. Livestock Production Science, v.68, p.131-139, 2001.

ARTHUR, P.F.; HERD, R.M. Residual feed intake in beef cattle. In: REUNIÃO ANUAL DA SOCIEDADE BRASILEIRA DE ZOOTECNIA, 45., 2008, Lavras. Anais... Lavras: Sociedade Brasileira de Zootecnia, 2008. p.269-279.

ARCHER, J.A.; ARTHUR, P.F.; HERD, R.M. et al. Optimum postweaning test for measurement of growth rate, feed intake, and feed efficiency in British breed cattle. Journal of Animal Science, v.75, p.2024-2032, 1997.

ARCHER, J.A.; RICHARDSON, E.C.; HERD, R.M. et al. Potential for selection to improve efficiency of feed use in beef cattle: A review. Australian Journal of Agriculture Research, v.50, p.147-161, 1999.

BAKER, S.D.; SZASZ, J.I.; KLEIN, T.A. et al. Residual feed intake of purebred Angus steers: Effects on meat quality and palatability. Journal of Animal Science, v.84, p.938-945, 2006.

BASARAB, J.A.; PRICE, M.A.; AALHUS, J.L. et al. Residual feed intake and body composition in young growing cattle. Canadian Journal of Animal Science, v.83, p.189-204, 2003.

BERGH, L.; SCHOLTZ, M.M.; ERASMUS, G.J. Identification and assessment of the best animal: The Kleiber ratio (growth/ metabolic mass) as a selection criterion for beef cattle. Proceedings... Australian Association of Animal Breeding Genetic, v.10, p.338-340, 1992.

BROWN, E.G. Sources of biological variation in residual feed intake in growing and finishing steers. 2005. 131f. Degree of Doctor of Philosophy (Nutrition) - Texas A\&M University, Texas.

CARSTENS, G.E.; THEIS, C.M.; WHITE, M.B. et al. Residual feed intake in beef steers: I. Correlations with performance traits and ultrasound measures of body composition. Proceedings... Western Section American Society Animal Science, v.53, p.552-555, 2002.

CASTILHO, A.M.; BRANCO, R.H.; CORVINO, T.L.S. et al. Feed efficiency of Nellore cattle selected for postweaning weight. Revista Brasileira de Zootecnia, v.39, n.11, p.2486-2493, 2010.

DITTMAR III, R.O. Determining biological sources of variation in residual feed intake in Brahman heifers during confinement feeding and on pasture. 2007. 111f. Degree of Master of Science (Animal Science) - Texas A\&M University, Texas.

FITZHUGH JUNIOR, H.A.; TAYLOR, C.S.St. Genetic analysis of degree of maturity. Journal of Animal Science, v.33, p.717-725, 1971.

GOLDEN, J.W.; KERLEY, M.S. Relationship of feeding behavior to feed efficiency in crossbred Angus steers. In: ANNUAL MEETING OF AMERICAN SOCIETY OF ANIMAL SCIENCE, 2004, Saint Louis. Proceedings... Saint Louis: American Society of Animal Science, 2004. p.410.

HERD, R.M.; BISHOP, S.C. Genetic variation in residual feed intake and its association with other production traits in British Hereford cattle. Livestock Production Science, v.63, p.111-119, 2000.

HERD, R.M.; ODDY, V.H.; RICHARDSON, E.C. Biological basis for variation in residual feed intake in beef cattle. 1. Review of potential mechanisms. Australian Journal of Experimental Agriculture, v.44, p.423-430, 2004.

HOQUE, M.A.; HOSONO, M.; OIKAWA, T. et al. Genetic parameters for measures of energetic efficiency of bulls and their relationships with carcass traits of field progeny in Japanese black cattle. Journal of Animal Science, v.87, p.99-106, 2009.

KOCH, R.M.; SWIGER, L.A.; CHAMBERS, D. et al. Efficiency of feed use in beef cattle. Journal of Animal Science, v.22, p.486-494, 1963.

LANNA, D.P.D.; ALMEIDA, R. Exigências nutricionais e melhoramento genético para eficiência alimentar: Experiências e lições para um projeto nacional. In: REUNIÃO ANUAL DA SOCIEDADE BRASILEIRA DE ZOOTECNIA, 41., 2004, Campo Grande. Anais... Campo Grande: Sociedade Brasileira de Zootecnia, 2004. (CD-ROM). 
LANCASTER, P.A.; CARSTENS, G.E.; RIBEIRO, F.R.B. et al. Characterization of feed efficiency traits and relationships with feeding behavior and ultrasound carcass traits in growing bulls. Journal of Animal Science, v.87, p.1528-1539, 2009.

MERCADANTE, M.E.Z.; RAZOOK, A.G.; CYRILLO, J.N.S.G. et al. Programa de Seleção da Estação Experimental de Zootecnia de Sertãozinho: resultados de pesquisas, sumário de touros Nelore. Nova Odessa: Instituto de Zootecnia, 2004. 35p. (Boletim Científico, 12).

NKRUMAH, J.D.; BASARAB, J.A.; PRICE, M.A. et al. Different measures of energetic efficiency and their phenotypic relationships with growth, feed intake, and ultrasound and carcass merit in hybrid cattle. Journal of Animal Science, v.82, p.2451-2459, 2004.

NKRUMAH, J.D.; CREWS JUNIOR, D.H.; BASARAB, J.A. et al. Genetic and phenotypic relationships of feeding behavior and temperament with performance, feed efficiency, ultrasound, and carcass merit of beef cattle. Journal of Animal Science, v.85, p.2382-2390, 2007.

NATIONAL RESEARCH COUNCIL - NRC. Nutrient requirements of beef cattle. 7.ed. Washington, D.C.: National Academy Press, 1996. 242p.

NIELSEN, M.K. Genetic variation in feed utilization: selection responses in mice. In: ANNUAL MEETING OF THE
AMERICAN SOCIETY OF ANIMAL SCIENCE, 2004, Saint Louis. Proceedings... Saint Louis: American Society of Animal Science, 2004. p.119.

RAZOOK, A.G.; FIGUEIREDO, L.A.; CYRILLO, J.N.S.G. et al. Prova de ganho de peso: Normas adotadas pela estação experimental de Zootecnia de Sertãozinho. Nova Odessa: Instituto de Zootecnia, 1997. 33p. (Boletim Científico, 40).

RICHARDSON, E.C.; HERD, R.M.; ARCHER, J.A. et al. Metabolic differences in Angus steers divergently selected for residual feed intake. Australian Journal of Experimental Agriculture, v.44, p.441-452, 2004.

SILVA, D.J.; QUEIROZ, A.C. Análise de alimentos: métodos químicos e biológicos. 3.ed. Viçosa, MG: Editora UFV, 2002. 235p.

STATISTICAL ANALYSIS SYSTEMS - SAS. SAS/STAT user's Guide, Version 8. Cary: SAS Institute, 1999. (CR-ROM).

VAN SOEST, P.J.; ROBERTSON, J.B.; LEWIS, B.A. Methods of dietary fiber, neutral detergent fiber, and nonstarch polysaccharides in relation to animal nutrition. Journal of Dairy Science, v.74, p.3583-3597, 1991.

WEISS, W.P. Energy prediction equations for ruminant feeds. In: CORNELL NUTRITION CONFERENCE FOR FEED MANUfACTURES, 61., 1992, Ithaca. Proceedings... Ithaca: Cornell University, 1992. p.176-185. 